DOI 10.37882/2223-2982.2021.04.25

\title{
СРАВНИТЕЛЬНЫЙ АНАЛИЗ ИЗМЕНЕНИЯ БИОХИМИЧЕСКИХ ПОКАЗАТЕЛЕЙ КРОВИ У СПОРТСМЕНОВ РАЗЛИЧНОЙ СПЕЦИАЛИЗАЦИИ ЛЕГКОЙ АТЛЕТИКИ
}

\section{COMPARATIVE ANALYSIS OF CHANGES IN BLOOD BIOCHEMICAL INDICATORS IN ATHLETES OF VARIOUS SPECIALIZATION OF ATHLETICS}

N. Panasyuk

Summary: Object: To conduct a comparative analysis of changes in the biochemical parameters of blood in athletes of various specialties of athletics, for the correct planning of the training process and the selection of funds.

Findings The experiment showed that regardless of the specialization, all athletes had changes in the average values of the studied peripheral blood parameters, especially an increase in the level of lactate, which reached the maximum values with the interval method of the training process in short and medium distance runners, and the pace load in athletes specializing in sports walking. In shot putters and all-rounders, the changes in blood parameters from the initial ones were lower. Conclusions: The optimal level of lactate concentration for the development of strength endurance is above $6 \mathrm{mmol} / \mathrm{l}$. For high-speed endurance training (short and medium distance running), the lactate level should be at least $8 \mathrm{mmol} / \mathrm{l}$. With prolonged maintenance of lactate levels above $11 \mathrm{mmol} / \mathrm{L}$, acidosis of muscle cells and intercellular space occurs, as evidenced by a more noticeable decrease in blood pH.

Keywords: Athletics, preparation period, planning of the training process, intensive loads, blood chemistry, lactate.

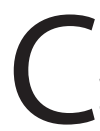

овременный уровень развития спорта предъявляет специальные требования к подготовке спортсменов.

Конечным результатом тренировочного процесса в легкой атлетике является достижение наивысших результатов, что в свою очередь зависит от рационального распределения средств и методов тренировочного процесса, соответствующих особенностям этапа спортивной подготовки.

Интенсивные физические нагрузки, которые переносят спортсмены, специализирующиеся в легкой атлетике, влияют на их метаболизм, что может отражаться на биохимических показателях крови. Изменения химического состава крови спортсмена во время физических

\author{
Панасюк Наталья Брониславовна \\ Преподаватель, Могилевский государственный \\ университет имени А.А. Кулешова; \\ тренер-преподаватель, Могилевский Областной Центр \\ Олимпийского Резерва по легкой атлетике и игровым \\ видам спорта \\ n.panasjuk1501@yandex.by
}

Аннотация: Цель данного исследования -провести сравнительный анализ изменения биохимических показателей крови у спортсменов различной специализации легкой атлетики, для правильного планирования учебно-тренировочного процесса и подбора средств.

Результаты: Эксперимент показал, что независимо от специализации у всех спортсменов наблюдались изменение средних значений исследуемых показателей периферической крови, особенно рост уровня лактата, который достигал максимальных значений при интервальном методе тренировочного процесса у бегунов на короткие и средние дистанции, и темповой нагрузке у спортсменов, специализирующихся в спортивной ходьбе. У толкателей ядра и многоборцев изменения показателей крови от исходных были ниже.

Выводы: Оптимальным уровнем концентрации лактата для развития силовой выносливости является показатель выше 6 мМоль/л. Для тренировки скоростной выносливости (бег на короткие и средние дистанции) уровень лактата должен быть не меньше 8 мМоль/л. При длительном сохранении уровня лактата свыше 11 мМоль/л происходит ацидоз мышечных клеток и межклеточного пространства, о чем свидетельствует более заметное снижение показателя рН крови.

Ключевые слова: легкая атлетика; подготовительный период; планирование тренировочного процесса; интенсивные нагрузки; химический состав крови; лактат.

нагрузок информируют тренера об изменениях, возникающих в организме при увеличении мышечной деятельности.

Лактат - соль молочной кислоты (молочная кислота образуется в результате анаэробного гликолиза и быстро преобразуется в лактат). Лактат имеет свойство накапливаться в связи с разницей скорости преобразования энергии в моменты аэробной и анаэробной нагрузки. В анаэробном режиме он является основным переносчиком энергии в сердце, дыхательные мышцы, медленно сокращающиеся мышечные волокна и другие группы мышц. При физической нагрузке лактат высвобождается из мышц и преобразуется в пируват. При значительном накоплении лактата в кровенном русле уменьшается Рн крови, что приводит к метаболическому ацидозу. 
Образование лактата возможно только в анаэробных условиях. Так же лактат имеет свойство накапливаться в связи с разницей скорости преобразования энергии в моменты аэробной и анаэробной нагрузки. В анаэробном режиме он является основным переносчиком энергии в сердце, дыхательные мышцы, медленно сокращающиеся мышечные волокна и другие группы мышц. При физической нагрузке лактат высвобождается из мышц и преобразуется в пируват. При значительном накоплении лактата в кровенном русле уменьшается Рн крови, что приводит к метаболическому ацидозу.

У спортсменов в связи с лактатацидозом отмечается заметное повышение уровня анионного разрыва (aGap), что свидетельствует о накоплении молочной кислоты, кетонов и фиксированных кислот в организме. Показатели анионного разрыва являются первым составляющим для определения уровня метаболического ацидоза.

Повышение уровня лактата у спортсменов свидетельствует о накоплении молочной кислоты, кетонов и фиксированных кислот в организме. В спортивной биохимии определение уровня лактата является маркером тканевой гипоксии; Концентрация лактата в крови во время тренировочного процесса менее 4 мМоль/л свидетельствует о недостаточной интенсивности нагрузки. Повышение уровня лактата в процессе тренировки напрямую связан с повышением уровня глюкозы в крови, т.к. происходит транспорт избытка лактата из мышц в печень с дальнейшим синтезом из него глюкозы (Цикл Кори).

Цель нашего исследования: провести сравнительный анализ изменения биохимических показателей крови у спортсменов различной специализации легкой атлетики, для правильного планирования учебно-тренировочного процесса и подбора средств.

Эксперимент проводился на базе Могилевского областного центра олимпийского резерва по легкой атлетике и игровым видам спорта, под руководством спортивного врача Хальчицкой Л.В., отвечающей за подготовку легкоатлетов города Могилева. Были обследованы группы спортсменов, имеющих специализацию: бег на средние дистанции, спортивная ходьба, бег на короткие дистанции, толкание ядра, легкоатлетическое многоборье. Все спортсмены в возрасте 18-20 лет и имеют квалификацию 1 разряд, КМС. Исследования проводились на втором этапе подготовительного периода, первого микроцикла нагрузки. От каждой специализации в эксперименте принимало участие по пять спортсменов.

В качестве основных показателей для исследования были взяты: кислотно-щелочной баланс $\mathrm{pH}$, парциальное давление углекислого газа рСО2, парциальное давление кислорода рО2, лактат, глюкозу. Процедура тестирования была следующая - использовался индивидуальный биохимический анализатор «Accutrend Plus». Уровень интересующих нас показателей определялся путем колориметрической лактат-оксидазной реакции. Забор крови проводился из фаланги пальца до-, непосредственно после и через 10 минут после тренировочного процесса.

В течение микроцикла все испытуемые выполняли тренировочную нагрузку, соответствующую специализации и данному этапу подготовки.

В беге на средние дистанции была выполнена следующая работа; 1 день микроцикла: разминка бег 2 км, растяжка, ускорения 5х50м, бег 400м с интенсивностью 70-80\%, чередуя с медленным бегом 400м - 6 серий. 2 день микроцикла: разминка бег 2 км, общеразвивающие упражнения, беговые и прыжковые упражнения, ускорения 5х100м, бег 600м с интенсивностью 65-75\% с минутным интервалом отдыха - 4 серии. 3 день микроцикла; разминка бег 1.5 км, общеразвивающие упражнения, бег 1200м с интенсивностью 60-70\%, через 200м, 300м, 600м легкого бега. 4 день микроцикла; разминка бег 3км, общеразвивающие упражнения, бег 400м с интенсивностью 70-80\% с интервалом отдыха 2 мин - 8 серий. 5 день микроцикла; разминка бег 1 км, беговые и прыжковые упражнения, кроссовый бег 10-15км.

В специализации спортивная ходьба была выполнена следующая работа; 1 день микроцикла: разминка бег 1 км, растяжка, темповая ходьба 200м - 4 серии, ходьба 8 км с интенсивностью 65-75\%. 2 день микроцикла: разминка бег 1 км, общеразвивающие упражнения, беговые и прыжковые упражнения, темповая ходьба с интенсивностью 75-85\%. 3 день микроцикла; разминка бег 1 км, общеразвивающие упражнения, темповая ходьба 12 км с интенсивностью 65-75\%. 4 день микроцикла; разминка бег 1 км, общеразвивающие упражнения, спортивная ходьба 3 км, темповая ходьба 200м - 6 серий. 5 день микроцикла; разминка бег 1 км, беговые и прыжковые упражнения, спортивная ходьба 20 км на пульсе 150-160 ударов в минуту.

В специализации бег на короткие дистанции, барьерный бег была выполнена следующая работа; 1 день микроцикла: разминка бег 1 км, растяжка, общеразвивающие упражнения, беговые и прыжковые упражнения, выбегание с низкого старта 2х30м, 2х40м, 2х50м с интенсивностью 70-80\% от максимальной, прыжки в шаге с ноги на ногу 6х10. 2 день микроцикла: разминка бег 1 км, общеразвивающие упражнения, беговые и прыжковые упражнения, выбегание с низкого старта под команду 8х50м с интенсивностью 75-85\%, бег с ускорением 5х150м с интенсивностью 70-80\%. 3 день микроцикла; разминка бег 1 км, общеразвивающие упражнения, специальные беговые и прыжковые упражнения, 
силовая тренировка приседания со штангой на плечах 50-60\%х10 - 3 серии, рывок штанги 50-60\%х6 - 3 серии, взятие штанги на грудь 40-50\%х10 - 3 серии. 4 день микроцикла; разминка бег 1 км, общеразвивающие упражнения, бег 200м с интенсивностью 65-75\% через 200м легкого бега - 5 серий. 5 день микроцикла; разминка бег 1 км, специальные беговые и прыжковые упражнения, выбегания с низкого старта 6 х60 с интенсивностью 8090\%, 3-ой прыжок с места - 10 повторений, броски ядра 40 повторений.

В специализации легкоатлетические многоборья была выполнена следующая работа; 1 день микроцикла: разминка бег 1.2 км, растяжка, общеразвивающие упраж- нения, беговые и прыжковые упражнения, выбегание с низкого старта с интенсивностью 70-80\% 5х30м, 2х40, 2х50, прыжки в шаге с ноги на ногу 4х30м, броски набивного мяча 50 раз. 2 день микроцикла: разминка бег 1 км, общеразвивающие упражнения, беговые и прыжковые упражнения, барьерный бег - пробегание 6 барьеров в 5 шагов, в 3 шага по 4 повторения, прыжки в высоту - 20 раз, толкание ядра 30 раз. 3 день микроцикла; разминка бег 1.5 км, общеразвивающие упражнения, силовая работа толчек штанги с груди 50-60\% х8 - 4 серии, рывок штанги 50\%х10 - 4 серии, жим штанги лежа 60\%х8 - 4 серии, пробегание отрезков 200+300+600. 4 день микроцикла; разминка бег 30 мин, упражнения на гибкость. 5 день микроцикла; разминка бег 1 км, специальные бе-

Таблица 1.

Значение средних показателей (СП) у бегунов на средние дистанции (мм.рт.ст, мМоль/л)

\begin{tabular}{|l|c|c|c|c|c|}
\hline & $\mathrm{pH}$ & $\mathrm{pCO2}$ & $\mathrm{p02}$ & Лактат & Глюк0за \\
\hline СП до тренировки & 7.38 & 34 & 78 & 5,58 \\
\hline СП после тренировки & 7.28 & 29 & 91 & $14,25(7.87-19.80)$ & 8,5 \\
\hline СП после 10 мин отдыха & 7.28 & 38 & 82 & 9,03 & 6,2 \\
\hline
\end{tabular}

Таблица 2. Значение средних показателей (СП) у спортсменов специализирующихся в спортивной ходьбе (мм.рт.ст, мМоль/л)

\begin{tabular}{|l|c|c|c|c|c|}
\multicolumn{1}{l|}{} & $\mathrm{pH}$ & $\mathrm{pCO2}$ & $\mathrm{p02}$ & Лактат & Глюкоза \\
\hline СП до тренировки & 7,38 & 40 & 62,5 & 1,71 & 5,4 \\
\hline СП после тренировки & 7,22 & 34,6 & 79,8 & $12,12(8.26-15.68)$ & 7,7 \\
\hline СП после 10 мин отдыха & 7,37 & 36,6 & 69,7 & 3,67 & 5,3 \\
\hline
\end{tabular}

Значение средних показателей (СП) у бегунов на короткие дистанции (мм.рт.ст, мМоль/л)

\begin{tabular}{|l|c|c|c|c|c|}
\hline & $\mathrm{pH}$ & $\mathrm{pCO2}$ & $\mathrm{p02}$ & Лактат & Глюкоза \\
\hline СП до тренировки & 7,38 & 43,53 & 80,20 & 1,18 & 5,8 \\
\hline СП после тренировки & 7,30 & 35,12 & 98,48 & $16,55(6.64-18.78)$ & 8,1 \\
\hline СП после 10 мин отдыха & 7,31 & 38,18 & 90,56 & 8,64 & 5,6 \\
\hline
\end{tabular}

Значение средних показателей (СП) у спортсменов специализирующихся

Таблица 4. в легкоатлетическом многоборье (мм.рт.ст, мМоль/л)

\begin{tabular}{|l|c|c|c|c|c|}
\hline & $\mathrm{pH}$ & $\mathrm{pC02}$ & $\mathrm{p02}$ & Лактат & Глюк0за \\
\hline СП до тренировки & 7,38 & 41,12 & 72,23 & 2,24 & 5,8 \\
\hline СП после тренировки & 7,34 & 34,93 & 85,84 & $7,08(5.64-9.43)$ & 5,9 \\
\hline СП после 10 мин отдыха & 7,36 & 37,65 & 77,18 & 3,01 & 5,9 \\
\hline
\end{tabular}

Таблица 5.

Значение средних показателей (СП) у спортсменов специализирующихся в толкании ядра (мм.рт.ст, мМоль/л)

\begin{tabular}{|l|c|c|c|c|c|} 
& pH & pC02 & р02 & Лактат & 1,23 \\
\hline СП до тренировки & 7,42 & 35,21 & 87,46 & 6,5 \\
\hline СП после тренировки & 7,35 & 40,84 & 88,83 & $6,47(4.72-8.16)$ & 4,9 \\
\hline СП после 10 мин отдыха & 7,41 & 37,82 & 82,12 & 2,03 & 5,0 \\
\hline
\end{tabular}


говые и прыжковые упражнения, пробегание отрезков 3х60м, 3х80м с интенсивностью 75-85\%, метание копья 30 бросков, прыжки в длину с разбега 30 прыжков.

Эксперимент показал, что независимо от специализации спортсменов, интенсивность тренировочной нагрузки на втором этапе подготовительного периода, первого микроцикла составляла в среднем $70-80 \%$ от максимальной.

У всех спортсменов наблюдались изменение средних значений исследуемых показателей периферической крови, особенно рост уровня лактата, который достигал максимальных значений при интервальном методе тренировочного процесса у бегунов на короткие и средние дистанции, и темповой нагрузке у спортсменов, специализирующихся в спортивной ходьбе.

У толкателей ядра и многоборцев, основной задачей тренировочного процесса которых является развитие скоростно-силовых качеств, изменения показателей крови от исходных были ниже.

По прошествии 10 минут отдыха значения исследуемых показателей у спортсменов, специализирующихся в толкании ядра и многоборье, практически вернулись к первоначальным, тогда как у бегунов на короткие и средние дистанции и спортсменов, специализирующихся в спортивной ходьбе, продолжали наблюдаться значительные изменения исследуемых показателей.

Оптимальным уровнем концентрации лактата для развития силовой выносливости (толкание ядра, многоборья) является показатель выше 6 мМоль/л. Для тренировки скоростной выносливости (бег на короткие и средние дистанции) уровень лактата должен быть не меньше 8 мМоль/л. При длительном сохранении уровня лактата свыше 11 мМоль/л (спортивная ходьба) происходит ацидоз мышечных клеток и межклеточного пространства, о чем свидетельствует более заметное снижение показателя $\mathrm{pH}$ крови.

Так же можно отметить, что к наиболее значительным изменениям показателей крови (снижение уровня $\mathrm{pH}$, повышение уровня лактата) приводит интервальный метод тренировки в анаэробной зоне интенсивности.

Однако значительные сдвиги кислотно-основного состояния крови во время тренировки свидетельствуют о необходимости тщательного контроля нагрузки и интервалов отдыха.

\section{ЛИТЕРАТУРА}

1. Панасюк Н.Б. Изменение уровня газоанализаторов крови у бегунов на средние дистанции в зависимости от специфики тренировочной нагрузки. / Н.Б. Панасюк// научный электронный журнал «Modern humanities success/yспехи гуманитарных наук» - №6 - c. 183-186

2. Янсен Петер, ЧСС, лактат и тренировки на выносливость: пер. с англ. / Янсен Петер. - Мурманск: Изд-во «Тулома», 2006. - 160 с.

3. Bex T., Baguet A., Achten E. Cyclic movement frequency is associated with muscle typology in athletes //Scand J Med Sci Sports. 2017. P. 223-229.

4. Purcell L.K. Sport nutrition for young athletes //Paediatr. Child. Health. 2013. P. 200-202. 